\title{
Consideration of Shoulder Injury Prevention and Rehabilitation Exercise for Overhead Sports Population
}

\author{
Young Jin Jo', Young Kyun Kim² \\ ${ }^{1}$ Galaxia SM \\ 2 Sports, Health, and Rehabilitation Major, Kookmin University, Korea
}

\begin{tabular}{|c|c|}
\hline & ABSTRACT \\
\hline $\begin{array}{l}\text { Received: February 12, } 2019 \\
\text { Accepted: April 20, 2019 } \\
\text { Published online: April 30, } 2019 \\
\text { Keywords: } \\
\text { Glenohumeral internal rotation } \\
\quad \text { deficit (GIRD) } \\
\text { Posterior shoulder tightness(PST) } \\
\text { Range of motion } \\
\text { Rotator cuff }\end{array}$ & $\begin{array}{l}\text { The main purpose of this article is to suggest orthopaedic-basic knowledge on evidence-based injury } \\
\text { prevention and rehabilitation exercise for overhead sports activity population such as throwing, tennis, } \\
\text { resistance training. Overhead sports activity population have glenohumeral joint internal rotation } \\
\text { deficit (GIRD), excessive external rotation, posterior shoulder tightness (PST), abnormal scapular position } \\
\text { and dyskinesis. These physical characteristics may elicit common shoulder injury such as subacromial } \\
\text { impingement syndrome, rotator cuff tendinopathy, consequently range of motion improvement exercise } \\
\text { and rotator cuff strengthening are needed in order to prevent it. Especially, sleeper stretching and horizontal } \\
\text { adduction stretching are sports-specific technique to improve for GIRD and PST, external rotator cuff } \\
\text { strengthening in side-lying position is recommended to adjust a balance strong internal rotator compared } \\
\text { with weak external rotator for rotator cuff exercise. Therefore, exercise specialist should examine shoulder } \\
\text { joint strength and range of motion before practical application, these exercise maneuvers can be used } \\
\text { extensively for shoulder injury prevention as well as rehabilitation exercise. }\end{array}$ \\
\hline
\end{tabular}

(c) The Asian Society of Kinesiology and the Korean Academy of Kinesiology

서론

반복적인 오버헤드 스포츠 활동의 참가는 증가된 가 쪽 돌림과 제한된 안쪽 돌림과 같은 어깨 관절의 특이적 적응 현상을 갖는 것으로 알려져 있다 [1]. 특히 던지기 활 동의 참가자들에게는 비주축 어깨와 비교하여 유의하게 큰 차이가 나타났으며 저항운동에 장시간 참가해 온 참 가자들 또한 이러한 특징을 뚜렷하게 갖는 것으로 조사 되었다(2-4). 이러한 관절의 특성 중 어깨 안쪽 돌림 결핍 (Glenohumeral Internal Rotation Deficit: GIRD)은 후방 어 깨 구축(posterior shoulder tightness: PST)과 함께 어깨 상 해의 주된 요인으로 보고되었다 $(5,6)$.

*Correspondence: Young Kyun Kim, College of Physical Education, Sports, Health, and Rehabilitation Kookmin University, Jeongneungro 77, Seongbuk-gu, Seoul, Korea; Tel: +82-2-910-6435; E-mail: ykkim2016@kookmin.ac.kr
뿐만 아니라 오버헤드 스포츠 참가 집단에 게는 강화 된 안쪽 돌림근과 약화된 가쪽 돌림 근육을 갖는 것으로 조사되어 돌림근띠 근육의 불균형이 있는 것으로 나타나 어깨 상해의 예방을 위하여 우선적으로 대처해야만 하는 요소로 인식되고 있다 $[2,3,7]$. 따라서 이러한 스포츠 참 가자들의 어깨 상해를 예방하고 상해 후 재활을 위해서는 어깨 관절의 적절한 가동 범위 및 유연성의 확보와 돌림 근띠 (회전근개, rotator cuff)의 근력 균형이 무엇보다 먼 저 필요하다[7-9].

이러한 오버헤드 스포츠 참가자들에 게 흔하게 나타나 는 어깨 상해의 위험 요소들(risk factors)의 운동학적 배경 연구를 통한 접근으로 어깨 상해를 예방하고, 상해 후 회 복을 위한 재활운동을 현장에서 적용하는 것이 중요하다. 그러므로 이 논문의 목적은 다양한 선행 연구들을 통해서 
밝혀진 의학적 근거를 바탕으로(evidence-based medicine) 오버헤드 스포츠 참가 집단의 어깨 상해 예방 및 재활 운 동에 대하여 분석하여 현장에서 오버헤드 스포츠 참가자 들 및 지도자들에 대해 도움을 제공하고자 한다.

\section{견갑상완 관절 관절가동범위의 회복}

어깨 후방의 구축과 안쪽 돌림 결핍은 어깨 상해의 공 통된 원인으로 알려져 왔다 [10-12]. 특히 안쪽 돌림 결 핍은 어깨 통증의 원인이며 오버헤드 스포츠 참가자들의 어깨 기능장애의 주된 원인으로 보고되었다 [13]. Myer 등(2006)은 병리적인 내적 충돌증후군(pathologic internal impingement) 있는 투수에 게서 $19.7^{\circ}$ 의 안쪽 돌림 결핍을 발 견하였으며 Wilk(2011)등은 안쪽 돌림 결핍을 가진 참가 자들의 상해 위험성이 1.9 배 높다고 하였다 $[5,14]$. 이러한 안쪽 돌림 결핍의 원인은 최근 어깨 후방 관절낭(posterior capsule)의 구축인 것으로 조사되었다 $[15,16]$. 어깨 후방 구축은 어깨 올림 중 상완골의 회전축을 전상방으로 밀어 내어 상완골의 비정상적인 관절운동을 만들어 낸다 [17]. 특히 어깨 올림 중 봉우리밑 공간의 넓이 감소로 이어져 봉우리밑 충돌 증후군과 같은 임상적 증상을 보다 쉽 게 만들어 낸다 $[14,18]$.

또한 이러한 관절의 특징 은 안쪽 돌림 결핍과 제한된 어깨 올림 가동범위를 동반하는 것으로 나타났다 [3]. 이 러한 관절의 특징 은 투수에 게서 가장 많이 나타나는 것 으로 알려져 있으며 특히 견갑상완 관절낭의 후하방 부 위(posteroinferior aspect)의 단축에 의해서 발생된다 [5]. 특히 투구 동작 시 공이 손끝에서 빠져 나간 후 발생되는 팔로우 스로우 중 감속을 위해 사용되는 신장성 스트레스 가 이러한 반응을 만들어 내는 것으로 알려져 있다 [19]. 이러한 힘은 최대 $1050 \mathrm{~N}$, 즉 자신의 체중에 $80 \%$ 까지 영 향을 미치는 것으로 나타났으며 수 회 동안 반복된 던지 기 활동은 증상의 악화를 가속시킨다 $[8,9]$.

팔로우 스로우 중 어깨는 안쪽 돌림이 일어나며 후하방 의 관절주머니를 더욱 후방 안쪽으로 회전한다. 이때 발생 되는 전방 신연력(distraction force)에 저항하기 위하여 어 깨 후방 근육은 반사적인 신장성 근력을 필요로 한다. 하지 만 어깨 관절의 근육들이 충분한 컨디션을 가지고 있지 않 는 다면 이러한 높은 반복적인 스트레스를 견딜 수 없게 되 어 관절와순 파열(superior labral anterior posterior: SLAP), 돌림근 건염과 같은 만성적인 질환에 놓이게 된다 $[7,11]$.
또한 이러한 후하방 관절주머니에 미치는 반복된 인장력 (tensile force)은 관절주머니의 비대(capsular hypertrophy) 와 같은 연부 조직의 변화를 만들어 내어 어깨 후방 구축을 가속화 시키는 것으로 보고하여 [20] 어깨 안쪽 돌림 결핍 과 후방 구축이 어깨 상해의 주된 원인이라고 하였다 [11, 13]. 어깨 후방의 관절주머니와 근육의 뺏뺏함(stiffness)은 투구 동작, 테니스, 핸드볼, 저항 운동과 같은 오버헤드 스 포츠 참가자들에 게 발생되는 주된 신체적 특성으로 알려 졌다 $[1-3,6,10,15,17,18]$. 그러므로 무엇보다 어깨 후방 과 안쪽 돌림의 관절 가동성(mobility)의 회복이 무엇보다 먼저 처치가 필요하다. 다양한 스트레칭 운동이 어깨 후 면 단축과 안쪽 돌림 결핍을 개선시키기 위해서 개발되어 왔다 $[12,21,22]$. 이러한 가동범위를 증가시키기 위해서 는 슬리퍼 스트레칭과 수평 내전 스트레칭이 가장 주로 사 용되며 최근 관절가동범위 확보에 대한 유의한 결과들이 보고되었다 $[22,23]$. 하지만 스트레칭 수행 전 어깨 후방 의 병리학적 느슨함(laxity)이 존재한다면 이러한 스트레 칭은 제한 할 필요가 있으며 반대로 어깨 후방의 관절주 머니의 구축이 발견된다면 관절가동화 기법이 함께 실시 되어 더 욱 큰 효과를 이끌어 낼 수 있다 $[21,24]$.

최근 선행 연구에서는 이러한 스트레칭 동작을 수행 할 때 견갑골이 안정되지 못 하면 견흉관절에서의 보상적 움직임이 발생되기 때문에 덜 효과적일 수 있다고 지적하 였다 $[22,25]$. 교차 팔 수평 내전 스트레칭 중에 어깨 후면 조직에 집중되지만, 견갑골을 제한시키지 못하면 축이 되 어야할 견갑골의 움직임이 발생되어 어깨 후면 조직을 고 립시키기 위한 스트레칭의 효율성을 떨어뜨린다. 비슷하 게도, 어깨 안쪽 돌림 중에 견갑골은 전방 경사가 일어나 므로 어깨 후면 구조에 집중하기 위한 움직임 능력의 효 율성을 제한한다 [26].

또한 견갑골의 안정화는 스트레칭, 돌림근띠 강화운 동과 동시에 또는 먼저 적용되어야 하는 어깨상해를 예방 하기 위한 운동이다. 견갑골운동이상 (Scapular Dyskineis: $\mathrm{SD}$ )은 오버헤드 스포츠 참가자들에 게서 자주 발생하며, 이는 돌림근띠 상해, 어깨충돌증후군, 안쪽 돌림 결핍 (GIRD) 등과 관련이 있으며 [27] 견갑골운동이상이 있는 대상자들은 견갑골 주변 근육의 활성도가 다른 것으로 나 타났다 [28] 따라서 견갑골 안정화 운동과 연계하여 스트 레칭과 돌림근띠 재활운동을 적용하여야 한다.

효과적인 스트레칭 운동은 돌림근과 후방 관절낭과 같 은 후면 어깨 연부조직에 집중될 수 있는 수평 내전과 안 
쪽 돌림의 두 가지 움직임을 모두 사용해야만 하고 보상 작용을 제한하기 위해서 반드시 견갑골의 안정화를 제공 해야만 한다 $[22,23,25]$.

\section{어깨 후면 구축과 안쪽 돌림 결핍 향상을 위 한 스트레칭 기법}

\section{슬리퍼 스트레칭}

슬리퍼 스트레칭(sleeper stretch)을 실시하기 위해서는 신체는 옆으로 누운 자세(side-lying position)를 취한다. 참 가자는 스트레치 될 어깨를 $90^{\circ}$ 굴곡하고 그리고 팔꿈치 또한 $90^{\circ}$ 구부린 채 옆으로 눕는다. 자세를 취하면 반대 팔 은 스트레치 될 팔을 안쪽 돌림 하도록 테이블 바닥을 향 하여 손목 근위부를 누르며 유지시킨다(Figure 1). 견갑골 은 스트레치하기 위해서 옆으로 누운 자세를 취함으로써 안정화 시킬 수 있다. 또한 어깨 거상의 각도를 다양하게 낮게 바꾸어 가며 후방 관절주머니의 다른 부위를 향상시 킬 수 있으며 특히 사체 연구를 통하여 견갑면의 올림 $30^{\circ}$ 의 안쪽 돌림 중 가장 효과적으로 후방 관절주머니를 늘 릴 수 있는 것으로 조사되었다 [29].

\section{수정된 슬리퍼 스트레칭}

이 스트레칭(modified sleeper stretch)은 기존의 스트레 칭의 직접적으로 옆으로 누운 자세와 달리 상체를 45 도 정 도 뒤로 더 기대어 수행된다. 이러한 자세는 상체의 체중 을 이용하여 견갑골을 더욱 안정화 시킬 수 있도록 도와 준다. 또한 어깨 충돌의 느낌을 최소화하기 위하여 어깨 굴곡을 45 도 줄인 뒤 실시된다.

\section{Rollover 슬리퍼 스트레칭}

견갑골의 안정화를 위해서 실시자의 양측 견봉 (acromion)이 바닥과 수직이 되도록 몸통은 더욱 앞으로 기울일 수 있다. 이와 같은 스트레칭 기법은 Rollover 스트 레칭으로 명명되며 이러한 자세는 견갑상완 관절을 더욱 수평 내전시켜 견갑골의 움직임을 완벽히 차단하여 보상 작용을 최소화되도록 만든다 [25].

\section{교차 팔 수평 내전 스트레칭}

교차-팔 수평 내전 스트레치(cross-body horizontal adduction stretch) 는 슬리퍼 스트레칭의 다른 대안 방법 으로 제시된다. 이 스트레치 기법은 후방 어깨 부위의 유 연성을 위하여 실시될 수 있다 [30]. 참가자는 견갑상완 관

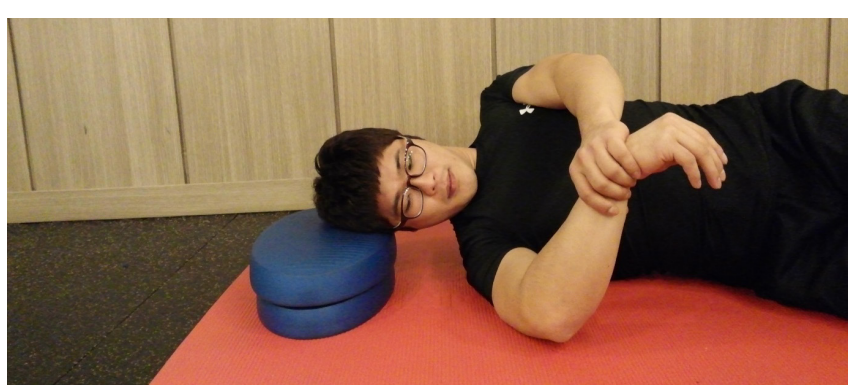

Figure 1. Sleeper stretching

절을 $90^{\circ}$ 굽히고 반대 손을 이용하여 팔의 팔꿈치 근위부 를 잡고 수평 내전 시키며 반대편 가슴 쪽으로 당긴다. 하 지만 이 때 축으로 작용해야할 견갑골이 움직여서 함께 외 전 된다면 스트레칭의 효과가 저하될 수 있으므로(Figure 2(a)) 반드시 견갑골의 움직임을 차단하고 수행되어야만 한다.(Figure 2(b)). 특히 어깨 후방 구축의 원인이 상완골 후경이 아닌 후방 관절주머니(posterior capsule)나 가시아 래근과 작은 원근과 같은 어깨 후면 근육의 문제라면 이 스 트레칭이 가장 효과적인 대안이 될 수 있다 $[12,22]$.

또한 운동전문가는 직접적으로 견갑골 안정화를 유 지 시킬 수 있다 [25]. 참가자가 등을 대고 누웠을 때 운동 전문가는 참가자의 옆에 서서 한쪽 손을 사용하여 견갑골 의 외측연(lateral border)을 테이블 바닥쪽으로 누른 후 다 른 한손을 이용하여 참가자의 팔꿈치 잡고 수평 내전 시 킬 수 있다. 이 때 팔꿈치를 잡은 손을 이용하여 전완을 참 가자의 아래쪽으로 돌린다면 어깨의 안쪽 돌림 스트레칭 을 함께 실시 할 수 있다(Figure 3(a)).

이러한 기법의 사용은 견갑골 안정화 없이 참가자 혼 자만 수행되는 방법과 비교하여 견갑골의 움직임을 최소 화함으로써 어깨 후방 연부조직의 유연성을 늘리는 데 가 장 효과적으로 기여하는 것으로 나타났다 $[25,30]$.

뿐만 아니라 비록 참가자에 게서 안쪽 돌림의 결함이 나타났을 지라도 수평 내전의 스트레칭도 반드시 프로그 램에 포함시켜야만 한다. 몇 몇 선행 연구에서는 수평 내 전의 스트레칭만으로도 견갑상완 관절의 안쪽 돌림이 증 가하였다는 것이 밝혀졌으며 슬리퍼 스트레칭 보다 수평 내전만 실시한 그룹에서 안쪽 돌림이 증가하였다고 보고 하였다 [12, 21].

만약 참가자가 혼자서 수행한다면 견갑골 안정화를 제 공하기 위해서 옆으로 누운 자세 또는 벽에 기댄 자세에 서 실시 할 수 있다. 슬리퍼 스트레칭과 마찬가지로 옆으 로 누워 상체의 체중을 이용하여 몸통을 약 30 도 뒤로 기 

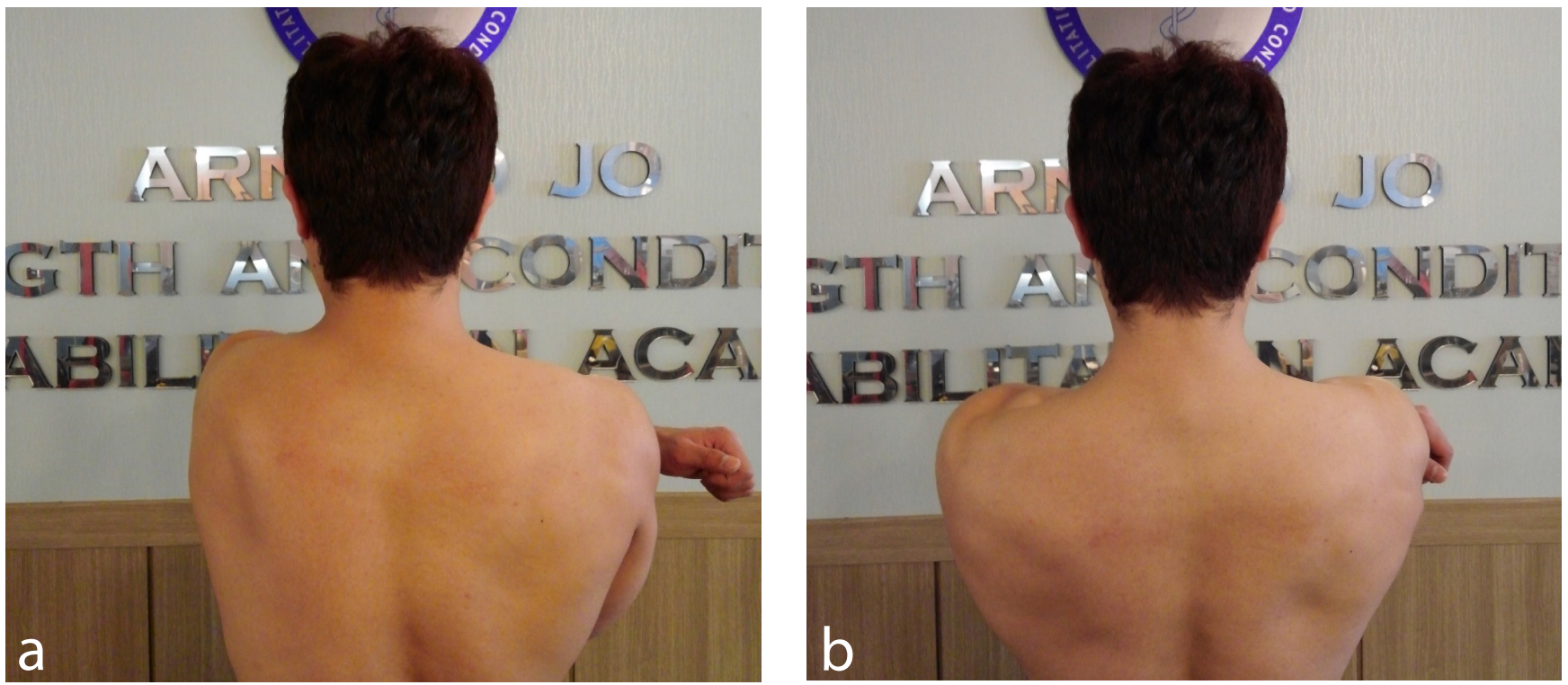

Figure 2. Incorrect position (scapular protracted)(a) and Corrected position (scapular retracted)(b).
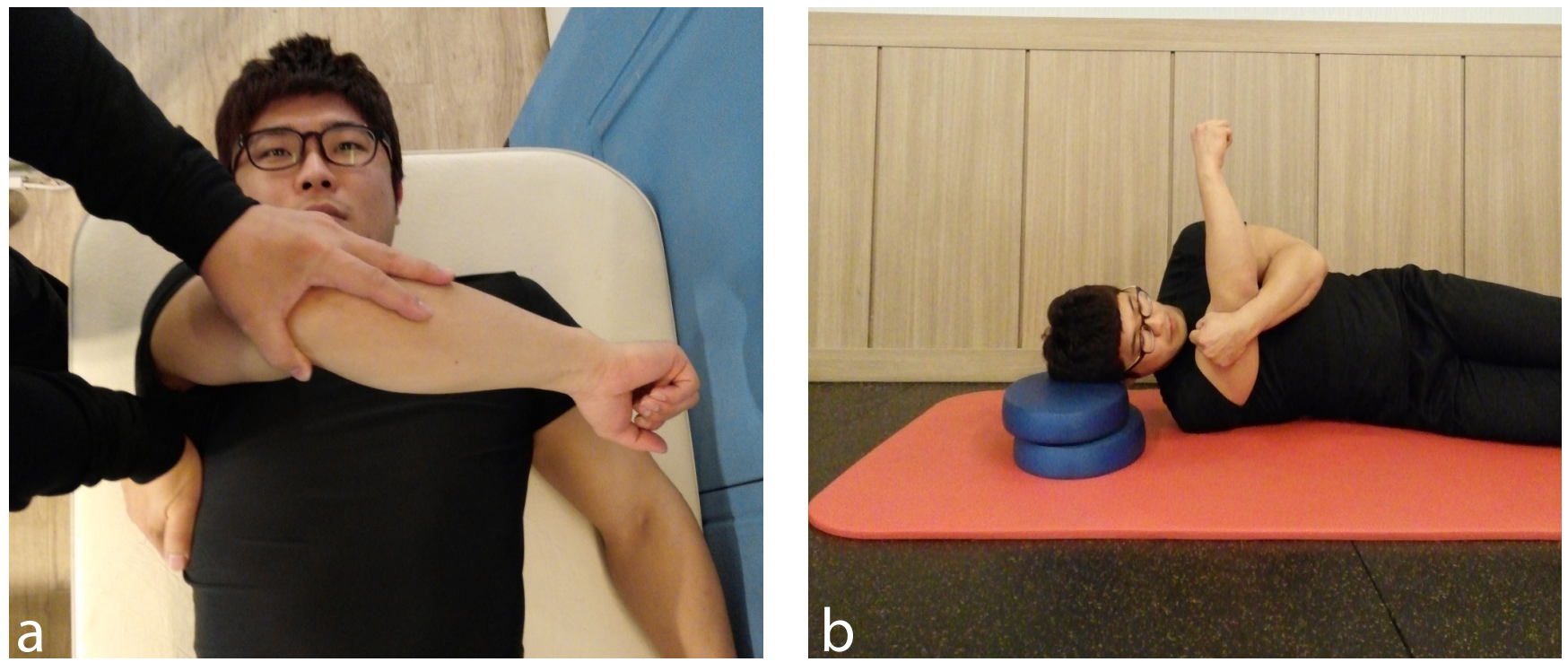

Figure 3. Passive shoulder horizontal adduction stretching with scapular stabilized (a) and self-shoulder horizontal adduction stretching (b).

울여 견갑골을 안정화 시킨 후 반대 팔을 이용하여 팔꿈 치를 반대편 가슴 방향으로 당긴다(Figure 3(b)).

\section{지니 스트레칭(Genie stretch)}

때때로 참가자는 보조자의 도움 없이 선 자세 또는 앉 은 자세에서 수평 내전과 함께 안쪽 돌림 움직임을 함께 만들어 낼 수 있다. 참가자는 허리를 곧게 펴고 앉아 한쪽 손으로 반대편의 팔꿈치를 감싸 수평 내전 방향으로 당김 과 동시에 팔꿈치를 이용하여 요골의 원위부를 아래 방향
으로 지그시 눌러 신장되는 팔의 안쪽 돌림을 만들어 낸다 (Figure 4(a)). 이 때 주의할 점은 스트레칭 되는 어깨가 올 라오지 않도록 반드시 견갑골의 내림을 유지시켜야만 한 다. 그렇지 않으면 봉우리밑 충돌의 통증을 감지하기 위 한 이학적 검사 중 하나인 Hawkins-Kennedy test 에서 발생 되는 몸통을 가로지르며 상완골의 안쪽 돌림된 채 거상의 움직임에 따른 영향으로 상완골이 봉우리밑 공간에서 충 돌이 발생 될 수 있다 [31](Figure 4(b)). 이러한 스트레칭 운 동은 오로지 유연성 향상을 목적으로 계획되어야만 한다. 

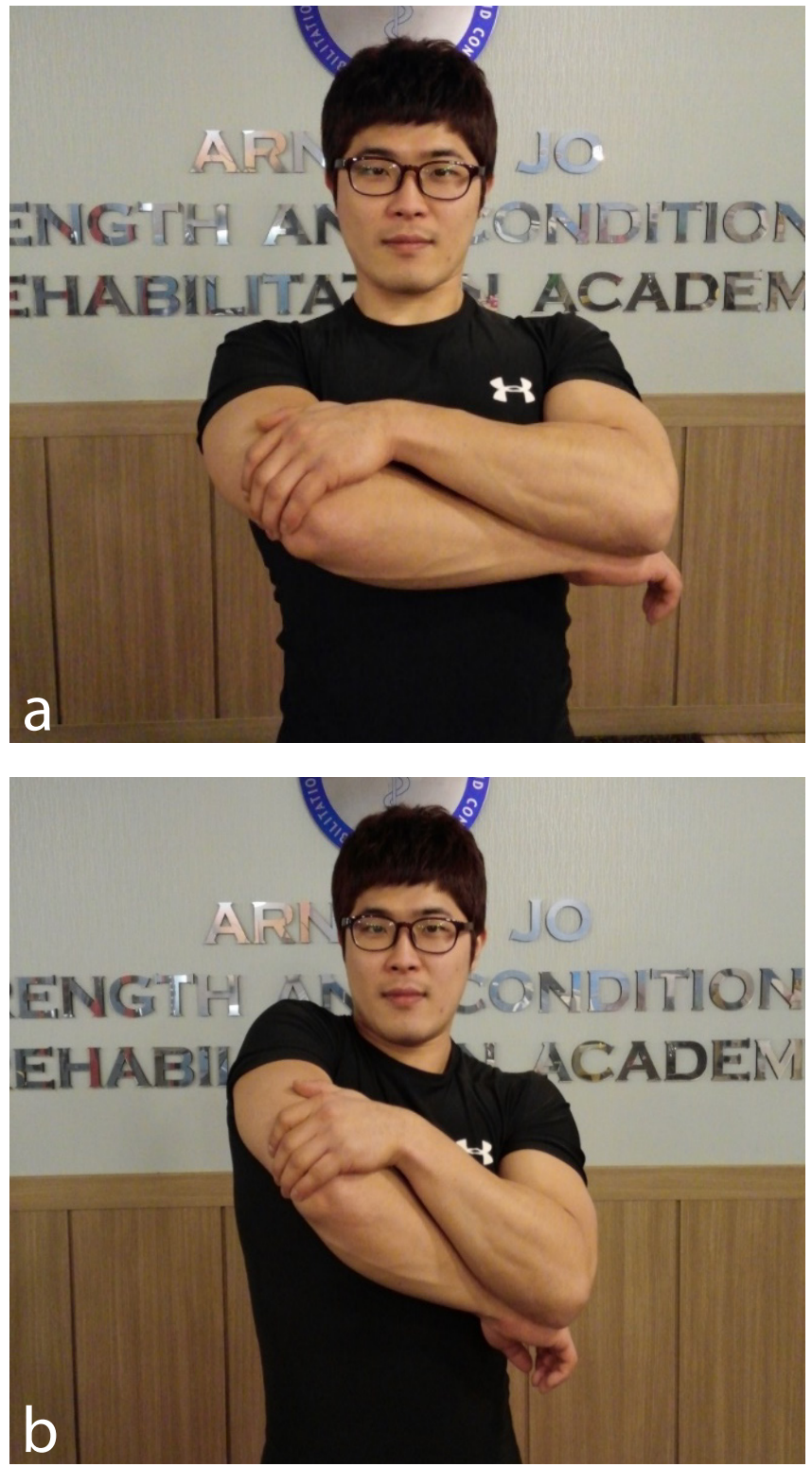

Figure 4. Correct position (a) and Incorrect position (b)

그러므로 운동전문가는 그것을 매일 기본적으로 수행 할 수 있도록 프로그램에 포함시킬 것을 권장한다. 권장 된 스트레칭 운동은 스트레칭의 효율성을 증명해온 연구 의 지침에 따라 사용된 지속 시간과 빈도는 각각 30 초간, 3 5회 실시해야만 한다. 일반적으로 스트레칭은 참가자 가 웜-업이 되었을 때 수행되어야만 하며 특히 스트레칭 의 효과는 근육의 온도가 증가했을 때 가장 효과적인 결 과를 만들어 낼 수 있는 것으로 알려져 있다 [32].

운동전문가는 각 스트레칭 운동의 강도등과 같은 변인 과 관련하여 참가자가 각 스트레칭 동작에서 약간 불편함
에서 유지할 수 있도록 지시할 것을 권장한다. 또한 재활의 단계와 개인의 통증 정도를 감안하여 스트레칭의 강도는 참가자가 불편함을 느끼기 시작되는 지점까지만 제한하 여야 한다. 만약 실시 중 참가자들이 지나치게 강하게 당 겨지는 느낌을 받는다면 스트레칭은 즉시 중단되어야만 한다. 일반적으로 스트레칭 프로그램에 심혈을 기울이는 참가자는 이러한 스트레칭 프로그램의 참가 후 즉시 안쪽 돌림과 수평 내전 가동 범위의 향상을 볼 수 있다 $[12,23]$.

\section{돌림근띠 (rotator cuff) 근력 강화 운동}

오버헤드 스포츠 활동 집단 중 근력의 불균형이 존재 하는 자들은 어깨의 상해 비율이 높은 것으로 보고되었다 [33]. 운동전문가는 가장 먼저 돌림근띠의 근력 불균형을 해결하는데 중점을 두어야만 한다. 특히 오버헤드 스포츠 참가에 의한 특수한 적응 현상으로 가쪽 돌림근의 근력의 감소가 나타났다 $[2,33]$. 뿐만 아니라 돌림근과 어깨 삼각 근의 근력 불균형은 어깨 올림 시 짝힘의 동원을 다르게 하여 우세해진 삼각근은 어깨 거상 시 상완골두를 상방 전 위 시켜 어깨 봉우리밑 충돌증후군을 심화시키는 것으로 보고하였다 $[8,34]$. 특히 오버헤드 스포츠 참가 집단에 게 는 어깨 삼각근 대 가시위근과 견갑하근의 근력이 유의하 게 낮게 나타난 것으로 보아 이러한 근육에 먼저 강화가 필요할 것이라고 사료된다 [3].

투수의 돌림근 건염과 파열은 던지기 기전에서 감속 중 수평 내전과 안쪽 돌림되는 팔의 전단력에 저항하기 위해 서 반복적으로 부과되는 가쪽 돌림 신장성 부하가 이러한 상해를 만들어 내는 것이라고 하였으며 내적 충돌 증후군 (internal impingement syndrome), 관절순 파열, 돌림근 건 염등과 같은 오버헤드 스포츠 참가관련 질환들이 가쪽 돌 림근의 약화에 기인하는 것이라고 주장하였다 [6]. 건강한 피험자를 대상으로 한 연구들에 비추어 견갑면의 어깨 외 전 90도에서 측정된 안쪽 돌림과 가쪽 돌림의 최상의 근력 비율은 66 75\%인 것으로 나타났다 [35].

그러므로 근력 강화프로그램을 이행하기 전 참가자의 돌림근의 근력 비율을 검사하는 것이 선행되어야 할 것으 로 사료된다. 최근 디지털 도수 근력계를 활용한 검사 방 법은 쉽고 빠르게 돌림근을 포함한 다양한 근력 측정에 사 용될 수 있다. 또한 이러한 측정법은 선행 연구들 통하여 높은 신뢰도와 타당도가 증명 되었으며 근력 검사 결과를 바탕으로 한 프로그램이 효과적이다 [36]. 


\section{가시위근 (supraspinatus) 을 위한 운동}

\section{캔 비우기(empty can) 대 캔 채우기(full can) 운동}

가시위근은 견갑골의 극상와에 기시하여 상완골두의 대결절에 정지하는 돌림근 근육 중 하나으로서 어깨 올 림 움직임 시 외전근(abductors)으로써 작용한다. 또한 상 완골 머리의 회전 중심을 관절순 내에서 움직일 수 있도 록 압박(compresses)하여 동적인 안정성을 제공하며 약간 의 가쪽 돌림 움직임을 도와주는 것으로 알려져 있다. 가 시위근의 활성도는 외전 또는 스캡션(scaption) 운동 중 저 항과 상관없이 $30 \sim 60^{\circ}$ 에서 가장 활성화 되며 특히 올림시 작 초반에 어깨 삼각근의 활성에 따른 상완골 머리의 상 방 활주에 저항하여 상완골 머리를 관절순 내에서 유지시 키는 작용을 한다. 상완이 거상됨에 따라 가시위근의 힘 팔 (moment arm)은 줄어들기 때문에 낮은 각도의 거상 중 가장 중요한 외전근으로서 작용한다 $[8,37]$.

다양한 선행 연구를 통해서 가시위근을 위한 가장 좋 은 운동이 제시되어 왔다 [34]. 그 중 캔 비우기 운동과 캔 채우기 운동은 논란의 대상이다. Jobe는 처음으로 가시위 근을 위한 운동을 견갑면에서 어깨 안쪽 돌림을 취하고 캔 비우기 운동을 실시할 것을 권장하였다 [38]. 하지만 이후 여러 선행 연구들이 가쪽 돌림 자세의 캔 채우기 운동을 선호하면서 가장 효과적인 운동에 관하여 다른 의견이 제 시되었다 [37]. Reinold(2007)등은 캔 채우기 운동, 캔 비우 기 운동, 앞으로 누워 캔 채우기(prone full can) 운동 중의 가시위근, 어깨 삼각근, 후면 어깨 삼각근의 근활성도 차 이를 비교분석하였다. 그 결과 세 가지 운동 모두 가시위 근의 근활성도는 최대 수의적 근수축(Maximal Voluntary Isometric Contraction: MVIC)의 62 67\%사이에서 나타나 통계적으로 유의한 차이가 나타나지 않은 반면 캔 채우기 운동은 다른 두 가지 운동과 비교하여 중간 및 후면(middle and posterior) 어깨 삼각근의 활성도가 유의하게 낮게 나 타난 것을 발견하였다 [34].

이러한 점은 임상적 고려되어야 할 부분으로 어깨 삼 각근은 팔의 올림 시 작은 외전 각도에서 상완골 머리를 견봉쪽으로 상방 활주(superior translation) 시킨다 [39]. 이 러한 움직임은 봉우리밑 공간을 쉽게 좁아지게 만들어 오 버헤드 스포츠 참가자들이 쉽게 어깨 충돌을 야기하는 관 절운동학적 근거로서 제시될 수 있다. 그러므로 올림 중 어깨 삼각근의 활성도를 감소시킨 채 가시위근이 함께 작 용한다면 상완골 머리는 관절순 내의 압박과 함께 어깨 충
돌 현상을 최소화할 수 있을 것이다 [8]. (Figure 5). 특히 캔 비우기와 캔 채우기 자세의 두 가지 운동 중 상완골 머리 의 안쪽 돌림과 가쪽 돌림에 따라서 다양한 임상적 고려 사항이 발생될 수 있다.
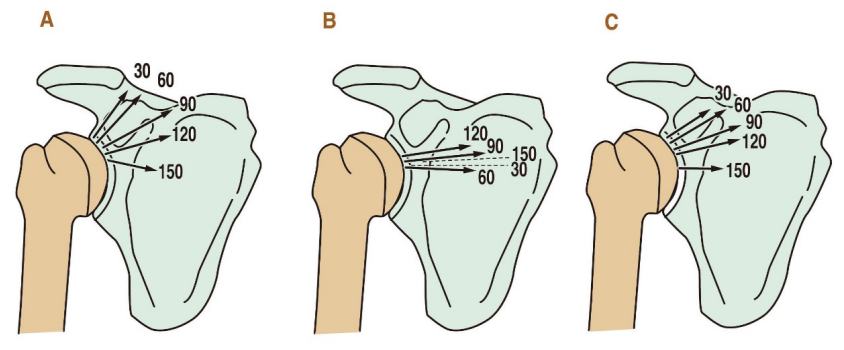

Figure 5. Directions of the magnitude of the resultant force vector for different glenohumeral joint positions as a function of different muscle activity. A-deltoid activity, B-rotator cuff activity, C-deltoid \& rotator cuff activity

첫째, 견갑상완 관절의 안쪽 돌림 및 가쪽 돌림에 따라 상완골 머리의 힘의 방향이 달라진다. 외전 $30^{\circ}$ 에서는 상 완골의 안쪽 돌림은 힘의 방향을 견쇄관절 방향의 위쪽으 로 만들어 내는 반면 가쪽 돌림 중에는 관절순내에 지속적 으로 위치시킨다. 거상의 각도가 증가함에 따라서 상완골 머리는 관절순 내에 유지되려고 하는 경향을 보인다. 이 는 왜 캔 비우기 운동 중에 약간의 올림동작만으로도 통 증과 불편함을 느끼는 지를 설명해 준다 [40] (Figure 6).

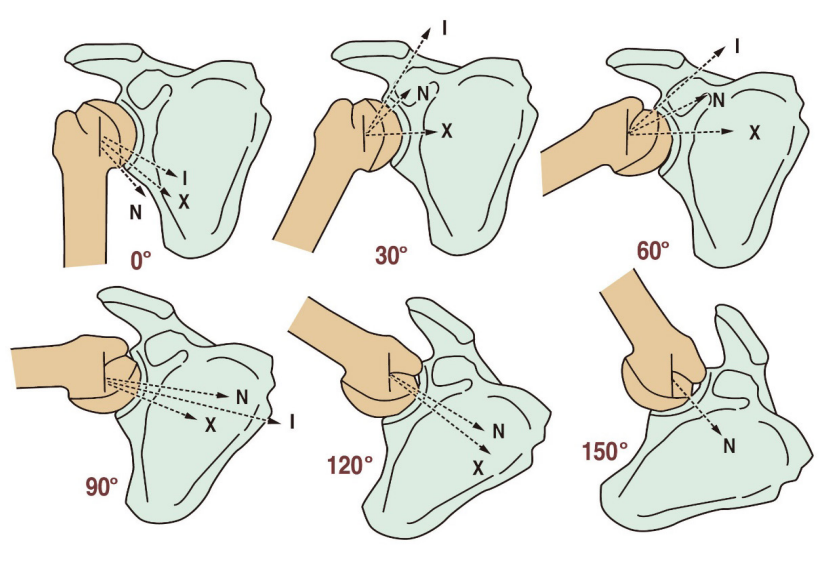

Figure 6. The position of the resultant force vector of the rotator cuff and deltoid for different positions of arm elevation. $\mathrm{N}$ - neutral rotation, Iinternal rotation, $\mathrm{X}$ - external rotation

둘째, 해부학적으로 캔 비우기 운동 중 견갑상완 관 절 안쪽 돌림 중 올림은 가시위근 힘줄의 정지점인 상완 골 머리의 대결절(the greater tuberosity)을 봉우리밑 공간 (subacromial space) 아래에 직접적으로 놓이게 하여 봉우 
리밑 공간의 반복적인 감소로 가시위근의 상해와 염증을 가중시킬 수 있다 [31].

셋째, 어깨 올림 0 90 중 가시위근의 외전 힘팔(the abduction moment arm)은 생체역학적으로 줄어들게 된 다. 이와 같은 불리한 기계적 이점은 가시위근의 더 큰 힘 생성의 요구를 발생시켜 상해를 입고 치유되는 조직에 더 큰 스트레스를 받게 만든다. 이러한 이유로 캔 비우기 운 동을 실시하는 참가자는 견갑골을 고정시킨 채 발생되는 올림 움직임이 아닌 견갑골을 으쓱하는 보상적인 동작을 하게 만든다 $[8,41]$.

넷째, 두 가지 운동 중 서로 다른 견갑골의 관절 운동학 적 차이를 발생시킨다. 최근 몇몇 선행 연구에서는 캔 비 우기 운동과 캔 채우기 운동 중 견갑골의 운동학과 근육의 활성도에 관하여 연구를 실시하였다. 그 결과 안쪽 돌림 된 채 수행되는 캔 채우기 운동 중에는 견갑골의 운동학 에서 유의하게 큰 안쪽 돌림, 전방 기울임 (anterior tilting), 전인(protraction)과 함께 유의하게 작은 후방 경사를 만들 어 내는 것으로 나타났다 $[40,42]$.

견갑골의 안쪽 돌림은 수평면에서 견쇄관절을 축으로 견갑골의 내측연(the medial border)이 흉곽으로부터 멀어 지며 회전이 일어나는 것이다. 전방기울임은 시상면에서 견갑골의 하각(the inferior angle)이 흉곽에서 멀어지며 발 생되는 회전이다. 전인은 전후면에서 견갑골의 내측연이 척수연으로부터 멀어지는 움직임을 말한다. 임상적으로 이러한 견갑골의 변형된 움직임은 상완골 머리와 견봉의 아래 공간인 봉우리밑 공간을 좁게 하여 반복적인 충돌 이 쉽게 만든다 [43].

그러므로 이러한 결과들을 바탕으로 운동전문가는 캔 채우기 운동이 가시위근을 위한 가장 적합한 운동으로 선 택할 수 있으며 참가자로 하여금 엄지손가락이 하늘을 향 하게 하여 상완골을 가쪽 돌림 시킨 채 수평면에서 전방 으로 약 $30^{\circ}$ 수평 내전하고 견갑면에서 수행할 것을 권장 한다 [41]. 또한 관절가동범위는 거상 $60^{\circ}$ 이하로 제한하 여 어깨 충돌과 어깨 삼각근의 동원을 최소화 할 수 있을 것으로 생각된다 $[7,9,34]$.

\section{가쪽 돌림근 (external rotator) 강화를 위한 운동}

\section{옆으로 누운 자세 가쪽 돌림근 근력 강화}

가쪽 돌림근 강화를 위한 최고의 운동에 관하여 많은 선행연구가 보고되었다 $[44,45]$. 다양한 자세에서 수행된

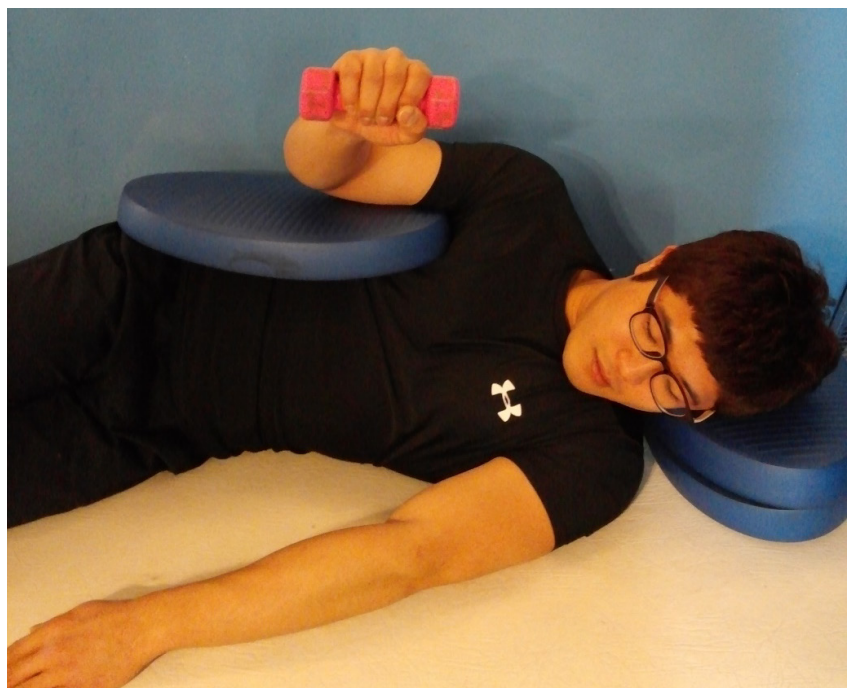

Figure 7. Side-lying external rotator exercise

가쪽 돌림근 운동 중 옆으로 누워 실시하는 가쪽 돌림 운 동이 가장 주의 깊게 살펴 볼 필요가 있다(Figure 7). 돌림 근 운동 중 가장 많이 발생되는 실수는 대흉근, 광배근, 어 깨 삼각근과 같은 큰 근육을 사용하여 돌림근에 가해지는 활성도를 낮추는데 있다 [46]. 특히 옆으로 누워 실시되는 덤벨 가쪽 돌림 운동이나 서서 실시되는 가쪽 돌림 밴드 운동 중 참가자들은 팔꿈치를 몸통에서부터 떨어뜨려 어 깨를 외전시켜 어깨 삼각근을 활성화시키는 경향이 있다 [44]. 이러한 옆으로 누운 자세에서 수행된 가쪽 돌림 근력 강화연구에서는 어깨 삼각근의 활성도가 가장 낮게 나와 돌림근 운동 중 어떠한 보상 작용(compensatory activity) 없 이 가시아래근과 소원근을 동원한다고 보고 하였다 [44]. 또한 팔꿈치와 몸통이 완벽하게 접촉된 어깨 내전된 자세 보다 약 $30^{\circ}$ 외전된 자세는 다양한 해부학적 및 생체역학 적인 장점을 가지게 된다. 팔꿈치와 허리 사이의 타월과 같은 지지대는 견갑상완 관절의 외전 및 올림을 약 $30^{\circ}$ 정 도 만들어 견갑면에서 수행되는 최적의 관절 움직임을 만 들어 낼 수 있으며 [44] 특히 어깨 삼각근의 활성도를 유의 하게 떨어뜨려 어깨 관절 주변의 대근육의 동원 없이 가 쪽 돌림근만을 강화할 수 있다 [45].

가쪽 돌림 근육은 견갑골의 외측연에서 기시하여 상완 골 머리의 대결절이 정지한다. 이 위치의 근육의 혈액 공 급은 견갑상(the suprascapular) 및 견갑하(subscapular) 동 맥에 의해서 이루어진다. 꽉 쪼여진(wringing out) 내전된 어깨는 이러한 혈액의 흐름에 부정적인 영향을 만들어 운 동 중 혈 액 공급을 차단하는 경향이 있는 것으로 나타났다 [47]. 이와 같은 운동 중 혈류의 부정적 영향을 피하기 위 
하여 팔꿈치와 몸통 사이의 지지 대를 사용하여 올림 $30^{\circ}$ 를 유지시키는 것은 내전근의 수축을 이용하여 외전근에 의한 보상작용을 막고 동시에 봉우리밑 공간을 확대하는 장점을 제공한다 [48]. 그러므로 이 운동 시 타월이나 고 무 패드를 이용하여 어깨 외전을 $30^{\circ}$ 유지 시키며 수행할 것을 권장한다.

\section{등 대고 누워서 신장성 가쪽 돌림 근력 강화}

최근 연구들은 돌림근의 신장성 근력에 더 욱 큰 관심 을 가지고 실시되었다. 왜냐하면 가쪽 돌림근의 신장성 근 력은 특히 투구 동작과 스매싱 후 어깨의 감속을 위하여 가장 큰 부하를 가쪽 돌림 근육의 신장성 수축에 의해서 감당해야하기 때문이다 $[7,9,46]$. 특히 최근 선행 연구에 서는 어깨 상해를 유발하는 것으로 알려진 안쪽 돌림 결 핍(GIRD)과 어깨 후방 구축(PST)의 원인이 후면의 관절 주머니의 단축이나 구축과 함께 반복된 던지기 후 발생된 신장성 부하의 가쪽 돌림 근육의 단축 때문인 것으로 밝 혀져 상해를 예방하기 위한 신장성 가쪽 돌림 근육의 수 축 능력에 초점을 두어야 한다고 보고하였다 [14]. 이러한 근육은 던지기, 서브, 스매싱과 같은 빠른 가속 움직임 후 감속을 위한 기능을 한다 [49].

이러한 점을 고려했을 때 신장성 근력 강화만을 위한 운동 또한 이용할 수 있다 [46]. 참가자는 밴드의 한쪽 끝 을 발가락에 묶고 고정 시킨 채 한손으로 밴드를 잡고 바 닥에 등을 대고 눕는다. 어깨와 팔꿈치를 각각 $90^{\circ}$ 외전 및 굴곡하고 다리를 폈을 때 적용된 밴드를 저항하며 어깨를 천천히 안쪽으로 움직인다. 이 때 가쪽 돌림 근육의 신장성 부하가 만들어진다. 마지막 자세에서는 무를을 구부림과 동시에 어깨를 어떠한 부하 없이 가쪽 돌림 시킨다. 뿐만 아니라 이러한 신장성 부하만을 위한 운동은 돌림근 건염 치료에도 효과적으로 사용될 수 있다 [50].

건강한 참가자들을 위한 프로그램 고안은 American College Sports Medicine (ACSM)의 지침에 따라 설정할 것 이 권장된다 [32]. 모든 운동 중의 강도와 부하는 근지구 력을 향상하기 위해 $1 \mathrm{RM}$ 의 $70 \%$ 강도로 $15 \sim 20$ 회 반복을 하도록 하며 세트는 기본적으로 2 3세트 수행한다. 세트 간 휴식 시간은 1 분 30 초 이하로 수행되어 지며 [32] 실시 자의 운동 중 상태에 따라 변인으로 수정하며 제시할 수 있다. 반면 수술 후 또는 상해 후 참가자는 증상과 정도에 따라 프로그램의 변인을 다르게 설정하는 운동전문가의 세심한 주의가 필요할 것으로 사료된다.

\section{결론 및 제언}

오버헤드 스포츠 참가자를 위한 어깨 상해 예방 및 재 활 운동 프로그램은 먼저 안쪽 돌림과 수평내전을 늘릴 수 있는 가동범위 운동과 균형이 갖추어진 돌림근 강화에 중 점을 둘 것을 권장한다. 단, 근력 운동 처방 실시 전 돌림 근띠의 근력 측정이 선행되어야 할 것으로 사료된다. 이 논문에서 제시한 운동이 오버헤드 스포츠 참가자들에 게 공통적으로 사용될 수 있는 운동 지침으로 활용될 수 있 기를 기대한다.

\section{Conflicts of Interest}

The authors declare no conflict of interest.

\section{References}

1. Amin NH, Ryan J, Fening SD, Soloff L, Schickendantz MS, Jones M. The relationship between glenohumeral internal rotational deficits, total range of motion, and shoulder strength in professional baseball pitchers. JAAOS. 2015; 23(12):789-96.

2. Jo Y-J, Kim Y-K. Different types of shoulder injuries of throwing and resistance training groups. J Kor Acad Kin. 2016; 18(3):73-83.

3. Kolber MJ, Beekhuizen KS, Cheng M-SS, Hellman MA. Shoulder joint and muscle characteristics in the recreational weight training population. J Strength Cond Res. 2009; 23(1):148-57.

4. Kolber MJ, Corrao M. Shoulder joint and muscle characteristics among healthy female recreational weight training participants. J Strength Cond Res. 2011; 25(1):231-41.

5. Myers JB, Laudner KG, Pasquale MR, Bradley JP, Lephart SM. Glenohumeral range of motion deficits and posterior shoulder tightness in throwers with pathologic internal impingement. Am J Sports Med. 2006; 34(3):385-91.

6. Wilk KE, Macrina LC, Arrigo C. Passive range of motion characteristics in the overhead baseball pitcher and their implications for rehabilitation. J Clin Orthop 
Related Res. 2012; 470(6):1586-94.

7. Wilk KE. The Athlete's Shoulder. Philadelphia, PA Churchill Livingstone/Elsevier; 2009.

8. Reinold MM, Escamilla R, Wilk KE. Current concepts in the scientific and clinical rationale behind exercises for glenohumeral and scapulothoracic musculature. J Orthop Sports Phys Ther. 2009; 39(2):105-17.

9. Wilk KE, Meister K, Andrews JR. Current concepts in the rehabilitation of the overhead throwing athlete. Am J Sports Med. 2002; 30(1):136-51.

10. Clarsen B, Bahr R, Andersson SH, Munk R, Myklebust G. Reduced glenohumeral rotation, external rotation weakness and scapular dyskinesis are risk factors for shoulder injuries among elite male handball players: a prospective cohort study. Br J Sports Med. 2014; 48(17):1327-33.

11. Lintner D, Noonan TJ, Kibler WB. Injury patterns and biomechanics of the athlete's shoulder. J Clin Sports Med. 2008; 27(4):527-51.

12. McClure P, Balaicuis J, Heiland D, Broersma ME, Thorndike CK, Wood A. A randomized controlled comparison of stretching procedures for posterior shoulder tightness. J Orthop Sports Phys Ther. 2007; 37(3):108-14.

13. Burkhart SS, Morgan CD, Kibler WB. Current Concepts: The disabled throwing shoulder: Spectrum of pathology part I: Pathoanatomy and biomechanics. Arthroscopy: J Arthro Related Surg. 2003; 19(4):404-20.

14. Wilk KE, Macrina LC, Fleisig GS, Porterfield R, Simpson CD, Harker P, et al. Correlation of glenohumeral internal rotation deficit and total rotational motion to shoulder injuries in professional baseball pitchers. Am J Sports Med. 2011; 39(2):329-35.

15. Bach HG, Goldberg BA. Posterior capsular contracture of the shoulder. JAAOS. 2006; 14(5):265.

16. Drakos MC, Rudzki JR, Allen AA, Potter HG, Altchek DW. Internal impingement of the shoulder in the overhead athlete. JBJS. 2009; 91(11):2719-28.

17. Manske RC, Grant-Nierman M, Lucas B. Shoulder Posterior internal impingement in the overhead athlete. Int J Orhtop Sports Phys Ther. 2013; 8(2):194-204.
18. Noonan TJ, Shanley E, Bailey LB, Wyland DJ, Kissenberth MJ, Hawkins RJ, et al. Professional pitchers with glenohumeral internal rotation deficit (GIRD) display greater humeral retrotorsion than pitchers without GIRD. Am J Sports Med. 2015; 43(6):1448-54.

19. Wilk KE, Macrina LC, Fleisig GS, Porterfield R, Simpson CD, II, Harker P, et al. Correlation of glenohumeral internal rotation deficit and total rotational motion to shoulder injuries in professional baseball pitchers. Am J Sports Med. 2011; 39(2):329-35.

20. Takenaga T, Sugimoto K, Goto H, Nozaki M, Fukuyoshi M, Tsuchiya A, et al. Posterior shoulder capsules are thicker and stiffer in the throwing shoulders of healthy college baseball players: a quantitative assessment using shear-wave ultrasound elastography. Am J Sports Med. 2015; 43(12):2935-42.

21. Manske RC, Meschke M, Porter A, Smith B, Reiman M. A randomized controlled single-blinded comparison of stretching versus stretching and joint mobilization for posterior shoulder tightness measured by internal rotation motion loss. J Sports Health. 2010; 2(2):94-100.

22. Salamh PA, Kolber MJ, Hanney WJ. Effect of scapular stabilization during horizontal adduction stretching on passive internal rotation and posterior shoulder tightness in young women volleyball athletes: a randomized controlled trial. Arch Phys Med Rehab. 2015; 96(2):349-56.

23. Laudner KG, Sipes RC, Wilson JT. The acute effects of sleeper stretches on shoulder range of motion. J Athl Train. 2008; 43(4):359-63.

24. Harshbarger ND, Eppelheimer BL, McLeod TCV, McCarty CW. The effectiveness of shoulder stretching and joint mobilizations on posterior shoulder tightness. J Sport Rehab. 2013; 22(4):313-9.

25. Wilk KE, Hooks TR, Macrina LC. The modified sleeper stretch and modified cross-body stretch to increase shoulder internal rotation range of motion in the overhead throwing athlete. J Orthop Sports Phys Ther. 2013; 43(12):891-4.

26. Ludewig PM, Reynolds JF. The association of scapular kinematics and glenohumeral joint pathologies. J 
Orthop Sports Phys Ther. 2009; 39(2):90-104.

27. Kibler WB, Ludewig PM, McClure PW, Michener LA, Bak K, Sciascia AD. Clinical implications of scapular dyskinesis in shoulder injury: the 2013 consensus statement from the 'Scapular Summit'. Br J Sports Med. 2013; 47(14):877-85.

28. Shin Y-A. Muscle activity during rehabilitation exercise in subjects with or without scapular winging. Asian J Kinesiology. 2013; 15:141-53.

29. Izumi T, Aoki M, Muraki T, Hidaka E, Miyamoto S. Stretching positions for the posterior capsule of the glenohumeral joint - Strain measurement using cadaver specimens. Am J Sports Med. 2008;36(10):2014-22.

30. Dong W, Goost H, Lin X-B, Burger C, Paul C, Wang Z-L, et al. Treatments for shoulder impingement syndrome a prisma systematic review and network meta-analysis. Medicine 2015; 94(10):undefined.

31. Roberts CS, Davila JN, Hushek SG, Tillett ED, Corrigan TM. Magnetic resonance imaging analysis of the subacromial space in the impingement sign positions. J Shoulder Elbow Surg. 2002; 11(6):595-9.

32. Garber CE, Blissmer B, Deschenes MR, Franklin BA, Lamonte MJ, Lee I-M, et al. Quantity and quality of exercise for developing and maintaining cardiorespiratory, musculoskeletal, and neuromotor fitness in apparently healthy adults: guidance for prescribing exercise. Med Sci Sports Exerc. 2011; 43(7):1334-59.

33. Stickley CD, Hetzler RK, Freemyer BG, Kimura IF. Isokinetic peak torque ratios and shoulder injury history in adolescent female volleyball athletes. J Athl Train. 2008; 43(6):571-7.

34. Reinold MM, Macrina LC, Wilk KE, Fleisig GS, Dun S, Barrentine SW, et al. Electromyographic analysis of the supraspinatus and deltoid muscles during 3 common rehabilitation exercises. J Athl Train. 2007; 42(4):464.

35. Ellenbecker TS, Davies GJ. The application of isokinetics in testing and rehabilitation of the shoulder complex. J Athl Train. 2000; 35(3):338-50.

36. Kolber MJ, Beekhuizen K, Cheng M-SS, Fiebert IM. The reliability of hand-held dynamometry in measuring isometric strength of the shoulder internal and external rotator musculature using a stabilization device. Phys Theo Prac. 2007;23(2):119-24.

37. Forbush SW, White DM, Smith W. The Comparison of the Empty Can and Full Can Techniques and a New Diagonal Horizontal Adduction Test for Supraspinatus Muscle Testing Using Cross-Sectional Analysis Through Ultrasonography. Int J Sports Phys Ther. 2013; 8(3):23747.

38. Jobe FW, Moynes DR. Delineation of diagnostic criteria and a rehabilitation program for rotator cuff injuries. Am J Sports Med. 1982; 10(6):336-9.

39. Arwert HJ, de Groot J, Van Woensel WW, Rozing PM. Electromyography of shoulder muscles in relation to force direction. J Shouler Elbow Surg. 1997;6(4):360-70.

40. Timmons MK, Ericksen JJ, Yesilyaprak SS, Michener LA. Empty can exercise provokes more pain and has undesirable biomechanics compared with the full can exercise. J Shoulder Elbow Surg. 2016; 25(4):548-56.

41. Yasojima T, Kizuka T, Noguchi H, Shiraki H, Mukai N, Miyanaga Y. Differences in EMG activity in scapular plane abduction under variable arm positions and loading conditions. J Med Sci Sports Exerc. 2008; 40(4):716-21.

42. Thigpen CA, Padua DA, Morgan N, Kreps C, Karas SG. Scapular kinematics during supraspinatus rehabilitation exercise - A comparison of full-can versus empty-can techniques. Am J Sports Med. 2006; 34(4):644-52.

43. Seitz AL, McClure PW, Lynch SS, Ketchum JM, Michener LA. Effects of scapular dyskinesis and scapular assistance test on subacromial space during static arm elevation. J Shoulder Elbow Surg. 2012; 21(5):631-40.

44. Reinold MM, Wilk KE, Fleisig GS, Zheng N, Barrentine SW, Chmielewski T, et al. Electromyographic analysis of the rotator cuff and deltoid musculature during common shoulder external rotation exercises. J Orthop Sports Phys Ther. 2004; 34(7):385-94.

45. Sakita K, Seeley MK, Myrer JW, Hopkins J. Shouldermuscle electromyography during shoulder externalrotation exercises with and without slight abduction. J 
Sports Rehabilitation 2015; 24(2):109-15.

46. Cools AM, Declercq G, Cagnie B, Cambier D, Witvrouw E. Internal impingement in the tennis player: rehabilitation guidelines. Br J Sports Med. 2008; 42(3):165-71.

47. Hegedus EJ, Cook C, Brennan M, Wyland D, Garrison JC, Driesner D. Vascularity and tendon pathology in the rotator cuff: a review of literature and implications for rehabilitation and surgery. Br J Sports Med. 2010; 44(12):838-47.

48. Hesse S, Schulte-Tigges G, Konrad M, Bardeleben A,
Werner C. Robot-assisted arm trainer for the passive and active practice of bilateral forearm and wrist movements in hemiparetic subjects. Arch Phy Med Rehab. 2003; 84(6):915-20.

49. Florschütz AV, Lane PD, Crosby LA. Shoulder: Infection after primary anatomic versus primary reverse total shoulder arthroplasty. J Shoulder Elbow Surg. 2015; 24(8):1296-301.

50. Lewis JS. Rotator cuff tendinopathy/subacromial impingement syndrome: is it time for a new method of assessment? Br J Sports Med. 2009; 43(4):259-64. 